\title{
Effects of luteotrophic and luteolytic hormones on expression of mRNA encoding insulin-like growth factor I and growth hormone receptor in the ovine corpus luteum
}

\author{
J. L. Juengel, T. M. Nett, R. V. Anthony and G. D. Niswender* \\ Animal Reproduction and Biotechnology Laboratory, Colorado State University, Fort Collins, \\ CO 80523-1683, USA
}

\begin{abstract}
The regulation of mRNAs encoding insulin-like growth factor I (IGF-I) and the receptor for growth hormone (GH-R) in ovine luteal tissue by luteotrophic and luteolytic hormones was examined. In Expt 1, ewes were hypophysectomized (HPX) on day 5 of the oestrous cycle and administered saline (S), LH, GH, or LH + GH until day 12 of the oestrous cycle $(n=4$ ewes per group). Concentrations of luteal mRNA encoding IGF-I in HPX $+S$ ewes and pituitary-intact ewes at day $5(n=4)$ were approximately $60 \%(P<0.05)$ of those in pituitary-intact ewes at day $12(n=4)$. Treatment of HPX ewes with $\mathrm{GH}$ or $\mathrm{GH}+\mathrm{LH}$, but not LH alone, increased concentrations of mRNA encoding IGF-I to values similar to those in pituitary-intact ewes at day 12 . Hypophysectomy also reduced the mean concentration of mRNA encoding GH-R to approximately $60 \%(P<0.05)$ of the values in pituitary-intact ewes (days 5 or 12 ). Treatment with $\mathrm{LH}$, but not $\mathrm{GH}$, increased $(P<0.05)$ concentrations of mRNA encoding GH-R to values observed in pituitary-intact ewes. In Expt 2, prostaglandin $\mathrm{F}_{2 \alpha}\left(\mathrm{PGF}_{2 \alpha^{\prime}}\right.$ I $\mu$ mole) injected into the ovarian artery on day II or day 12 of the oestrous cycle had no effect on luteal concentrations of mRNA for either IGF-I or GH-R. In Expt 3, concentrations of mRNA encoding IGF-I increased $(P<0.05)$ between days 3 and 6 and remained high for the duration (days 9,12 and 15) of the oestrous cycle while luteal concentrations of mRNA encoding GH-R did not change. In conclusion, responsiveness of the corpus luteum to $\mathrm{GH}$ and luteal synthesis of IGF-I are likely regulators of luteal development and function. However, $\mathrm{PGF}_{2 \alpha}$-induced luteolysis was not associated with a decrease in concentrations of mRNAs encoding either IGF-I or GH-R.
\end{abstract}

\section{Introduction}

Luteinizing hormone (LH) has long been considered to be the major luteotrophic hormone in sheep and cattle (reviewed by Niswender and Nett, 1994); however, local intra-ovarian regulation of luteal development and function may also be important (reviewed by Smith et al., 1994). Growth hormone (GH) was shown to be required together with LH for normal luteal development in ewes (Juengel et al., 1995). The discovery that luteal cells contain receptors for GH (Carlsson et al., 1993; Lucy et al., 1993) suggests that GH may have a direct role in luteal development or function. However, GH may also influence luteal development or function by increasing the secretion of insulin-like growth factor I (IGF-I) as luteal tissue also contains receptors for IGF-I (Parmer et al., 1991; Talavera and Menon, 1991; Obasiolu et al., 1992; Sauerwein et al., 1992; Perks et al., 1995) and GH has been shown to induce synthesis of IGF-I in the ovary (Davoren and Hseuh, 1986).

Insulin-like growth factor I is known to influence follicular cell growth and division as well as differentiation and steroid

*Correspondence.

Revised manuscript received 17 April 1997.

secretion (reviewed by Adashi et al, 1985a). One mechanism by which IGF-I influences follicular cells is through upregulation of gonadotrophin receptors (Adashi et al., 1985b). Upon binding to its receptor, IGF-I also increases the ability of FSH to stimulate CAMP formation, thus potentiating the effect of these hormones on follicular development (Adashi et al., 1986, 1988). The addition of IGF-I to bovine luteal cells or tissue increases the secretion of progesterone and oxytocin (McArdle and Holtorf, 1989; Sauerwein et al., 1992). Receptors for IGF-I are found exclusively on large luteal cells in rats and addition of IGF-I to cuitures of large, but not small, luteal cells increases progesterone production (Parmer et al., 1991). Rabbit and human luteal cells also respond to exogenous IGF-I with increased secretion of progesterone (Constantino et al., 1991; Devoto et al., 1995). Receptors for $\mathrm{GH}$ have also been localized to large luteal cells in bovine corpora lutea (Lucy et al., 1993). Collectively, these findings indicate that GH and IGF-I may be important in luteal development or function. Therefore, the objectives of the present experiments were to determine the effects of luteotrophic and luteolytic hormones on steady-state concentrations of mRNAs encoding luteal IGF-I and the $\mathrm{GH}$-receptor (GH-R) and to examine expression of these mRNAs during the oestrous cycle in ewes. 


\section{Materials and Methods}

Unless otherwise specified, all materials used in these experiments were purchased from Sigma Chemical Company, St Louis, MO or Fisher Scientific, Denver, CO.

\section{Generation of cDNAs encoding IGF-I and GH receptor}

Complementary DNA encoding IGF-I was generated by amplifying cDNA synthesized from mRNA isolated from bovine liver with primers specific for bovine IGF-I $\left(5^{\prime}\right.$ bases 91-110; 3' bases 781-800; Fotsis et al., 1990). Briefly, $2 \mu \mathrm{g}$ total cellular RNA was reverse transcribed with Moloney murine leukaemia virus reverse transcriptase using oligo $d T$ as primer. Polymerase chain reaction was carried out using primers specified above with 35 cycles of denaturing at $94^{\circ} \mathrm{C}$ for $1 \mathrm{~min}$, annealing at $60^{\circ} \mathrm{C}$ for $1 \mathrm{~min}$ and extension at $72^{\circ} \mathrm{C}$ for $1 \mathrm{~min}$. This $709 \mathrm{bp} \mathrm{cDNA}$ was ligated into the Sma I site of $p B S I I-S K$ (Stratagene, San Diego, CA) and sequenced (Chen and Seeburg, 1985) from both ends to confirm its identity. Bases 91-504 (Fotsis et al, 1990) of this cDNA were isolated by restriction digest of the plasmid-insert with Bam-HI and Eco-RI and used for northern and slot blot analysis following incorporation of ${ }^{32} \mathrm{P}$-dCTP $\left(3000 \mathrm{Ci} \mathrm{mmol}^{-1}\right.$; Amersham, Arlington Heights, IL) by the random primer method (Feinberg and Volgelstein, 1983). This region is $98 \%$ identical between ovine and bovine IGF-I cDNAs.

Complementary DNA encoding GH-R was generated by amplifying cDNA synthesized from mRNA isolated from ovine fetal liver with primers specific for ovine GH-R $\left(5^{\prime}\right.$ bases 235-255; 3' bases 648-668; Adams et al., 1990; Pratt and Anthony, 1995). Conditions for RT-PCR were as described for generation of the IGF-I cDNA. This 433 base pair cDNA was cloned into pCR II (Invitrogen, San Diego, CA) and sequenced (Chen and Seeburg, 1985) from both ends to confirm its identity. This plasmid was digested with Eco-RI to release the insert to use in northern and slot blot analysis following incorporation of ${ }^{32} \mathrm{P}$-dCTP (3000 Ci mmol ${ }^{-1}$; Amersham) with the random primer method (Feinberg and Volgelstein, 1983).

\section{Northern blot analysis}

Total cellular ( $t c$ ) RNA was isolated from ovine heart, adrenal gland, skeletal muscle, brain, corpora lutea (mid-luteal phase) and liver by organic extraction (Chomczynski and Sacchi, 1987). Polyadenylated (poly $\mathrm{A}^{+}$) RNA was isolated from tcRNA with PolyAttract ${ }^{\text {(R) }}$ mRNA isolation systems (Promega, Madison, WI). Duplicate aliquots of $8 \mu \mathrm{g}$ poly $\mathrm{A}^{+}$ from each tissue were separated by electrophoresis on a $1.5 \%$ agarose-formaldehyde-3[N-morpholino]propanesulfonic acid gel and transferred to nylon filters (Hybond, Amersham) by capillary action (Sambrook et al., 1989). RNA was cross-linked to filters by UV light (Stratalinker, La Jolla, CA). Filters were prehybridized overnight at $42^{\circ} \mathrm{C}$ in hybridization buffer $\left(5 \times \mathrm{SSC}\left(750 \mathrm{mmol} \mathrm{NaCl} 1^{-1}\right.\right.$ and $75 \mathrm{mmol}$ sodium citrate $\left.\mathrm{I}^{-1}\right), 0.1 \%(\mathrm{w} / \mathrm{v})$ Ficoll $400,0.1 \%(\mathrm{w} / \mathrm{v})$ polyvinylpyrrolidone, $0.1 \%(\mathrm{w} / \mathrm{v})$ BSA (US Biochemicals, Cleveland, $\mathrm{OH}), 0.1 \%$ $(\mathrm{w} / \mathrm{v})$ SDS, $50 \%(\mathrm{v} / \mathrm{v})$ deionized formamide (Gibco BRL, Gaithersburg, MD), $50 \mathrm{mmol} \mathrm{NaPO}_{4} \mathrm{l}^{-1}$, and heat-denatured salmon sperm DNA $\left.\left(100 \mu \mathrm{g} \mathrm{ml}^{-1}\right)\right)$. The filter was then incubated in hybridization buffer containing $2 \times 10^{6}$ c.p.m. ${ }^{32} \mathrm{P}$-labelled IGF-I or GH-R cDNA ml ${ }^{-1}$ at $42^{\circ} \mathrm{C}$ for $24 \mathrm{~h}$. After hybridization, filters were washed twice in double-strength SSC, $0.1 \%$ SDS at room temperature for $15 \mathrm{~min}$ followed by a wash in 0.1 strength SSC, $0.1 \%$ SDS at $50^{\circ} \mathrm{C}$ (IGF-I) or $65^{\circ} \mathrm{C}$ $(\mathrm{GH}-\mathrm{R})$ for $30 \mathrm{~min}$. Filters were then exposed to Kodak X-AR film (Eastman Kodak, Rochester, NY) for $4-11$ days at $-70^{\circ} \mathrm{C}$.

\section{Experimental design}

All experiments were approved by the Colorado State University Animal Care and Use Committee. Western range ewes (3-6 years old; $40-70 \mathrm{~kg}$ ) were housed in dry lot pens and fed $1.8-2.0 \mathrm{~kg}$ alfalfa per day and had free access to water. The oestrous cycles of the ewes averaged $17+1$ days and $79 \%$ of ewes used in Expts 2 and 3 had two or three corpora lutea.

Experiment 1. In Expt 1, ewes displaying signs of behavioural oestrus in the presence of vasectomized rams were assigned to one of six groups. Only multiple ovulating ewes (as determined by laparotomy on day 5 of the oestrous cycle) were used in this experiment to ensure collection of sufficient quantities of luteal tissue for biochemical analyses. On day 5 of the oestrous cycle (oestrus = day 0), 16 ewes were hypophysectomized using the transnasal, transphenoidal approach (Clarke et al., 1983; Farin et al., 1990). Hypophysectomized ewes were randomly assigned to receive saline (S), LH, GH, or $\mathrm{LH}$ and $\mathrm{GH}$. Luteinizing hormone and $\mathrm{GH}$ replacement regimens were designed to approximate normal luteal profiles. Further details of this experiment are given in Juengel et al. (1995). Ewes receiving $\mathrm{LH}(\mathrm{HPX}+\mathrm{LH}$ or $\mathrm{HPX}+\mathrm{LH}+\mathrm{GH}$; $n=4$ ewes per group) were injected with $4.0 \mu \mathrm{g}$ oLH (NIAMDD-oLH-24) in $1 \mathrm{ml}$ saline containing $1 \% \mathrm{BSA}$ at $4 \mathrm{~h}$ intervals through an indwelling jugular cannula. Ewes receiving $\mathrm{GH}$ ( $\mathrm{HPX}+\mathrm{GH}$ or $\mathrm{HPX}+\mathrm{LH}+\mathrm{GH} ; n=4$ ewes per group) were injected subcutaneously with $1.5 \mathrm{mg}$ recombinant bovine GH (Sometribove, donated by Monsanto, St Louis, MO) in $0.3 \mathrm{ml}$ saline every $12 \mathrm{~h}$. Ewes were treated from the time of hypophysectomy until collection of luteal tissue on day 12 of the oestrous cycle. In addition, four pituitary-intact ewes (day 12 control) were laparotomized on day 5 of the oestrous cycle to observe the number of corpora lutea and received saline injections on the same schedule as the HPX $+\mathrm{S}$ group until luteal collection on day 12. Corpora lutea were also collected from the four pituitary-intact ewes (day 5 control) on day 5 of the oestrous cycle. After collection, corpora lutea were decapsulated, weighed, sliced with a hand microtome, frozen in liquid nitrogen and stored at $-70^{\circ} \mathrm{C}$ until isolation of RNA. A blood sample was obtained just before collection of corpora lutea. Concentrations of progesterone in sera were determined in a single radioimmunoassay (Niswender, 1973; coefficient of variation $(\mathrm{CV})=6 \%$, assay sensitivity $=50 \mathrm{pg} \mathrm{ml}^{-1}$ ).

Experiment 2. Ewes on day 11 or 12 of the oestrous cycle were placed under general anaesthesia with pentobarbital ( $25 \mathrm{mg} \mathrm{kg}^{-1}$ body weight) and the reproductive tract exteriorized through a midline ventral incision. The ovarian artery ipsilateral to either ovary bearing one or more corpora lutea Downloaded from Bioscientifica.com at 04/26/2023 09:49:15AM 
was cannulated with a 25 gauge needle attached to a $15 \mathrm{~cm}$ piece of Silastic tubing and $1 \mu$ mole $\mathrm{PGF}_{2 u}$ (in $1 \mathrm{ml}$ saline containing $1 \%$ dimethyl sulfoxide; DMSO) was infused for I min with a $1 \mathrm{ml}$ tuberculin syringe as described by McGuire et al. (1994). Ewes were killed I h $(n=6), 4 \mathrm{~h}(n=5), 12 \mathrm{~h}$ $(n=5)$ or $24 \mathrm{~h}(n=5)$ after infusion and corpora lutea collected, decapsulated, weighed, frozen in liquid nitrogen and stored at $-70^{\circ} \mathrm{C}$ until isolation of RNA. Corpora lutea were also collected as described above from ewes on day 11 or 12 of the oestrous cycle ( $0 \mathrm{~h}, n=3$, non-infused controls) or from ewes that were infused with $1 \mathrm{ml}$ saline-1\% DMSO $12 \mathrm{~h}(n=3)$ or $24 \mathrm{~h}(n=4)$ before luteal collection (saline-infused controls). Blood samples were collected from all ewes at the time of collection of corpora lutea for determination of concentrations of progesterone in resulting sera in a single radioimmunoassay (Niswender, $1973, \mathrm{CV}=12 \%$, sensitivity $=66 \mathrm{pg} \mathrm{ml}^{-1}$ ).

Experiment 3. Corpora lutea were removed from ewes on days $3,6,9,12$ or 15 of the oestrous cycle (oestrus= day 0 ), decapsulated, weighed, frozen in liquid nitrogen and stored at $-70^{\circ} \mathrm{C}$ until isolation of RNA. Four replicates (containing corpora lutea collected from one to five ewes per replicate depending on day of the oestrous cycle and number of corpora lutea per ewe) of luteal tissue were generated for each day of the cycle examined. Serum was obtained by centrifugation of jugular blood samples collected from each ewe at the time of corpora lutea removal and pooled according to replicate for each day for quantification of progesterone content (Niswender, 1973; intra-assay $\mathrm{CV}=16 \%$, sensitivity $=68 \mathrm{pg} \mathrm{ml}^{-1}$ ).

\section{Quantification of mRNA encoding IGF-I and GH-R}

Individual luteal samples were homogenized in lysis buffer (200 mmol $\mathrm{NaCl} \mathrm{l}^{-1}, 200 \mathrm{mmol}$ Tris $\mathrm{I}^{-1}, 1.5 \mathrm{mmol} \mathrm{MgCl}_{2}$ $\mathrm{I}^{-1}, 2 \% \mathrm{SDS}$, and $0.4 \mathrm{mg}$ proteinase $\mathrm{K} \mathrm{ml}^{-1}$ ), and poly $\mathrm{A}^{+}$ RNA was isolated as described by Badley et al. (1988) following binding to oligo(dT)-cellulose (Collaborative Biomedical Products, Bedford, MA). The amount of poly $\mathrm{A}^{+}$ RNA isolated per gram of luteal tissue was not affected by treatments. There was no indication of mRNA degradation in experimental samples as assessed by northern blot analysis using cDNAs encoding P450 side-chain cleavage enzyme or steroidogenic acute regulatory protein. Amounts of specific IGF-I and GH-R mRNA in each sample were measured by applying $300-500 \mathrm{ng}$ poly $\mathrm{A}^{+}$RNA in duplicate to nylon filters with a slot blot apparatus. Standard curves were generated by transcribing sense RNAs from appropriate plasmids linearized with Bam $\mathrm{HI}$ (IGF-I) or Apa I (GH-R). Various amounts $(300,100,50,30,10,5,3 \mathrm{pg})$ of sense RNAs were applied to the filters in each assay in duplicate. In addition, various amounts $(50,100,300,500 \mathrm{ng})$ of mRNA isolated from corpora lutea collected from ewes on day 10 of the oestrous cycle were included on each filter as positive controls. All RNA was cross-linked to filters with UV light (Stratalinker; Stratagene). Prehybridization, hybridization and washing of filters were as described for northern blot analysis. After each final wash, filters were exposed to Kodak X-AR film for 2-21 days. Owing to the limited amount of RNA available in Expts 2 and 3 , the amount of mRNA encoding GH-R was determined after

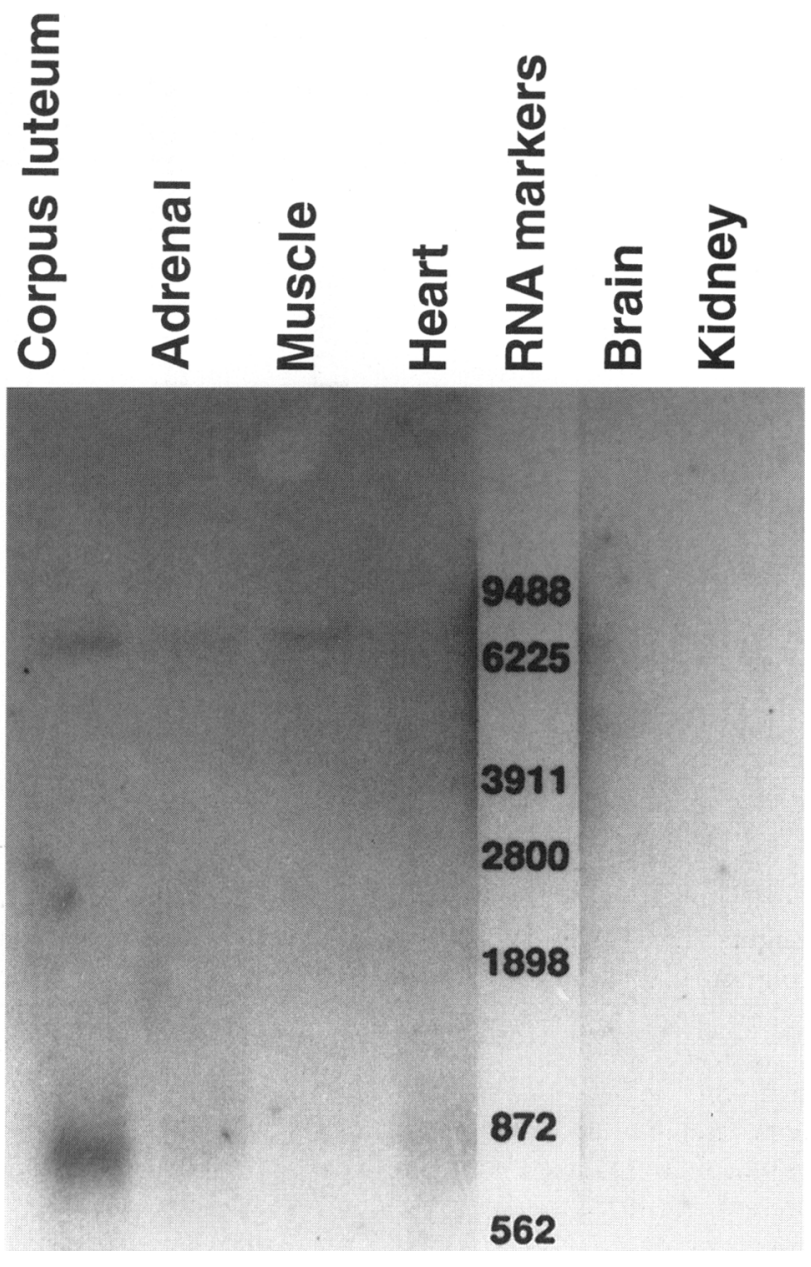

Fig. 1. Autoradiograph following northern blot analysis of poly $\mathrm{A}^{+}$ RNA $(8 \mu \mathrm{g})$ isolated from various ovine tissues hybridized to bovine cDNA encoding insulin-like growth factor I. Source of RNA is indicated at the top of each lane. Migration of RNA markers is indicated.

removal of the IGF-I cDNA from the filter by washing in boiling $0.1 \%$ SDS. Removal of IGF-I CDNA was confirmed by exposure of filters to X-AR film.

For determining whether equal amounts of poly $A^{+}$RNA were loaded onto slots within each filter, following hybridization to the IGF-I or GH-R cDNAs, all filters were hybridized with ${ }^{32} \mathrm{P}$ end-labelled $\mathrm{dT}(18)$ as described by Juengel et al. (1994). Correlation between four different concentrations of RNA applied to the filter and densitometric signal was high $\left(R^{2}=0.93 \pm 0.01\right)$. The coefficient of variation between densitometric reading of samples averaged $14 \pm 2 \%$ for all filters; therefore, measurements of mRNA encoding IGF-I or GH-R were not corrected for differences in RNA loading. Determination of the amount of specific mRNA was made by comparing densitometric readings for samples to those of standards on autoradiograms. The amount of mRNA encoding IGF-I and GH-R was linear when measured over the range of 100-500 ng pooled luteal poly $\mathrm{A}^{+}$RNA. Recovery of cold standard when added to $300 \mathrm{ng}$ poly $\mathrm{A}^{+}$RNA isolated from ovine brain (negative for IGF-I and GH-R mRNA) was $97 \%$ for IGF-I and 


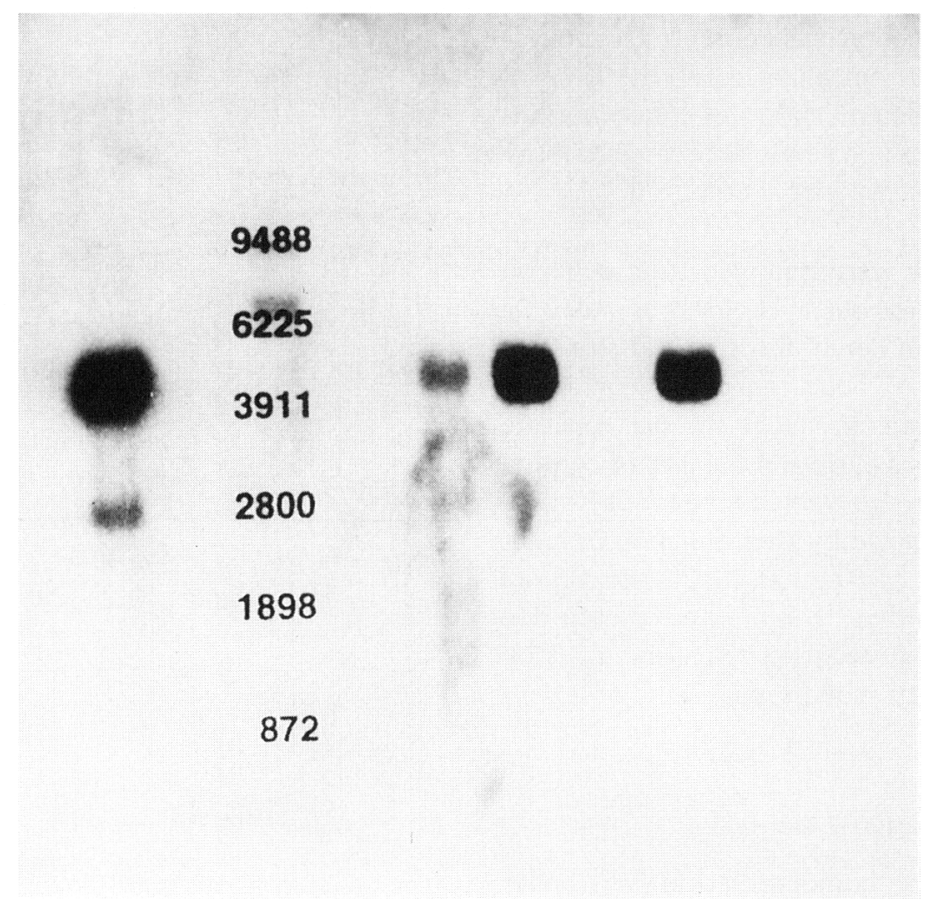

Fig. 2. Autoradiograph following northern blot analysis of poly $A^{+}$RNA $(8 \mu \mathrm{g})$ isolated from various ovine tissues hybridized to ovine cDNA encoding growth hormone receptor. The source of RNA is indicated at the top of each lane and migration of RNA markers is indicated.

$109 \%$ for GH-R. Intra-assay coefficients of variation averaged $9 \pm 2 \%$ and $12 \pm 2 \%$ for IGF-I and GH-R, respectively. Interassay coefficients of variation were $8 \%$ and $19 \%$ for IGF-I and GH-R, respectively. Sensitivity was 0.08 and $0.18{\text { fmoles } \mu \mathrm{g}^{-1}}^{-1}$ poly $\mathrm{A}^{+}$RNA for IGF-I and GH-R, respectively. All standard curves were linear and correlations between amount of standard added and resulting densitometric readings averaged $0.97 \pm 0.01$ for IGF-I and GH-R.

\section{Statistical analyses}

Data were analysed using the general linear model procedure of SAS (SAS, 1987). In Expt 1, concentrations of progesterone in serum were different among groups on day 5 of the oestrous cycle; therefore, the model included concentrations of progesterone in serum on day 5 as a covariate. In Expt two, no differences were observed for any parameter measured among the $\mathrm{O} h$ non-infused controls and the 12 or $24 \mathrm{~h}$ saline-infused controls; therefore, data from these three groups were combined for final statistical analysis and are referred to as $0 \mathrm{~h}$. In all three experiments differences between least square means were evaluated by least significant differences (SAS, 1987).

\section{Results}

Complementary DNA encoding bovine IGF-I specifically hybridized to mRNA of approximately 7100 and 675 bases in corpora lutea, adrenal, muscle (Fig. 1) and liver (data not shown) RNA. There was no detectable hybridization in mRNA isolated from kidney, brain and heart tissue (Fig. 1). Minor signals at approximately 3800 and 2400 bases were also observed in luteal tissue RNA (data not shown). The calculated sizes of mRNAs encoding IGF-I in this study are similar to those reported for mRNAs encoding IGF-I in rat, bovine and ovine luteal tissue (Einspanier et al., 1990; Parmer et al., 1991; Leeuwenberg et al., 1995).

Ovine cDNA encoding GH-R specifically hybridized to mRNA of approximately 4800 bases in poly $\mathrm{A}^{+}$RNA isolated Downloaded from Bioscientifica.com at 04/26/2023 09:49:15AM 
Table 1. Serum concentrations (LSM \pm SEM) of progesterone, luteal mass and luteal concentrations of mRNA encoding IGF-I and GH-receptor in control pituitary-intact ewes and hypophysectomized ewes treated with saline, $\mathrm{LH}, \mathrm{GH}$, or $\mathrm{LH}+\mathrm{GH}$

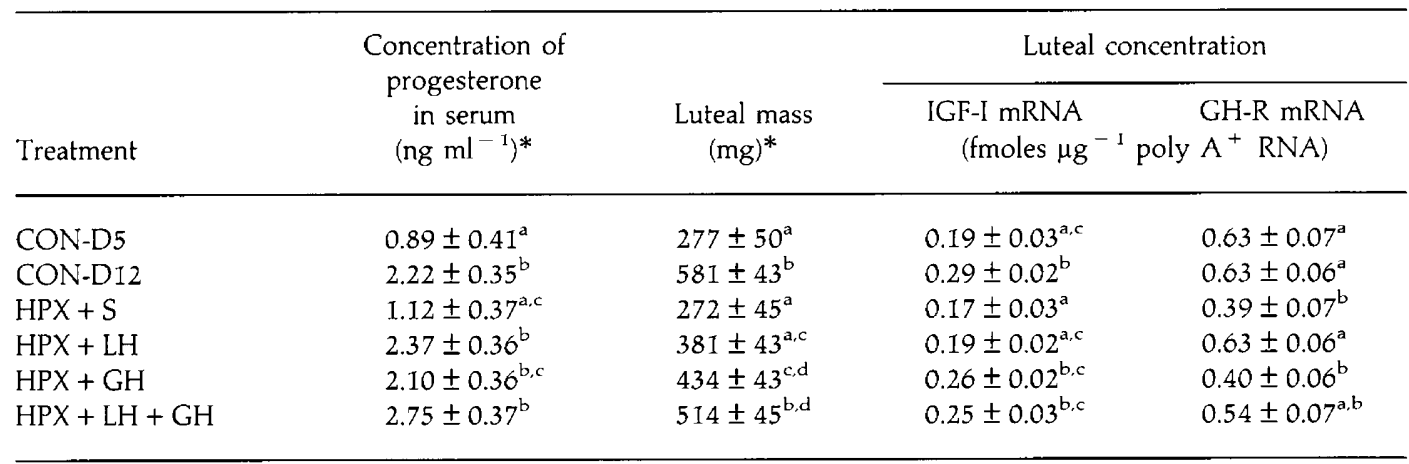

IGF-I: insulin-like growth factor I; GH-R: growth hormone receptor; CON-D5: pituitary-intact, day 5 of oestrous cycle; CON-D12: pituitary-intact, day 12 of oestrous cycle; HPX + S: hypophysectomized ewes administered saline.

*Data have been published by Juengel et al. (1995).

$a, b, c, d$ Within each parameter, means with different letters are significantly different $(P<0.05)$.

Table 2. Serum concentrations ( $\mathrm{LSM} \pm \mathrm{SEM}$ ) of progesterone, luteal mass and luteal concentrations of mRNA encoding IGF-I and GH-receptor following $\mathrm{PGF}_{2 \alpha}$ induced luteolysis in ewes

\begin{tabular}{|c|c|c|c|c|}
\hline \multirow{2}{*}{$\begin{array}{l}\text { Time }(h) \\
\text { after PGF } \\
\text { injection }\end{array}$} & \multirow{2}{*}{$\begin{array}{l}\text { Concentration of } \\
\text { progesterone } \\
\text { in serum } \\
\left(\mathrm{ng} \mathrm{ml} \mathrm{m}^{-1}\right)^{*}\end{array}$} & \multirow[b]{2}{*}{$\begin{array}{l}\text { Luteal mass } \\
\qquad(\mathrm{mg})^{*}\end{array}$} & \multicolumn{2}{|c|}{ Luteal concentration } \\
\hline & & & $\begin{array}{l}\text { IGF-I mRNA } \\
\text { (fmoles } \mu \mathrm{g}\end{array}$ & $\begin{array}{l}\text { GH-R mRNA } \\
\mathrm{A}^{+} \text {RNA) }\end{array}$ \\
\hline 0 & $1.73 \pm 0.11^{\mathrm{a}}$ & $594 \pm 32^{\mathrm{a}}$ & $0.32 \pm 0.02$ & $0.38 \pm 0.05$ \\
\hline 1 & $1.06 \pm 0.14^{b, c}$ & $532 \pm 42^{\mathrm{a}}$ & $0.28 \pm 0.03$ & $0.39 \pm 0.06$ \\
\hline 4 & $1.37 \pm 0.15^{\mathrm{a}, \mathrm{b}}$ & $648 \pm 47^{\mathrm{a}}$ & $0.32 \pm 0.03$ & $0.38 \pm 0.07$ \\
\hline 12 & $0.85 \pm 0.15^{\mathrm{c}}$ & $526 \pm 47^{\mathrm{a}}$ & $0.32 \pm 0.03$ & $0.41 \pm 0.07$ \\
\hline 24 & $0.24 \pm 0.15^{d}$ & $378 \pm 47^{\mathrm{b}}$ & $0.35 \pm 0.03$ & $0.30 \pm 0.07$ \\
\hline
\end{tabular}

PGF $_{2 u^{2}}$ : prostaglandin $\mathrm{F}_{2 \mathrm{u}^{\prime}}$ IGF-I: insulin-like growth factor I; GH-R: growth hormone receptor.

*Data have been published by Guy et al. (1995).

a,b,c,dWithin each parameter, values with different letters are significantly different $(P<0.05)$.

from corpora lutea, liver, kidney and muscle. No hybridization was observed in poly $\mathrm{A}^{+}$RNA isolated from brain, heart, and adrenal tissue (Fig. 2). A minor band at approximately 2800 bases was also observed in mRNA isolated from liver. The hybridizing mRNA is similar in size to mRNA for GH-R reported in bovine corpora lutea (Lucy et al., 1993; Vandehaar et al., 1995) and ovine liver (Pratt and Anthony, 1995).

In Expt 1, concentrations of mRNA encoding IGF-I (Table 1) in $\mathrm{HPX}+\mathrm{S}$ ewes were similar to those observed in control ewes at day 5 but lower $(P<0.05)$ than values obtained from control ewes at day 12. Concentrations of mRNA encoding IGF-I in HPX + LH ewes were similar to those observed in $\mathrm{HPX}+\mathrm{S}$ ewes and lower $(P<0.05)$ than values observed in control ewes at day 12. Concentrations of mRNA encoding IGF-I in $\mathrm{HPX}+\mathrm{GH}$ or $\mathrm{HPX}+\mathrm{LH}+\mathrm{GH}$ ewes were higher $(P<0.05)$ than those observed in $\mathrm{HPX}+\mathrm{S}$ ewes and similar to values obtained from control ewes at day 12 . Concentrations of mRNA encoding GH-R (Table $\mathrm{I}$ ) decreased in HPX $+\mathrm{S}$ ewes when compared with values obtained from control ewes at day 5 or day 12. Corpora lutea collected from HPX $+\mathrm{LH}$ ewes but not $\mathrm{HPX}+\mathrm{GH}$ ewes had higher $(P<0.05)$ concentrations of mRNA encoding the $\mathrm{GH}$ receptor compared with corpora lutea collected from HPX $+S$ ewes. In Expt 2, steady-state concentrations of mRNAs encoding IGF-I and GH-R did not change following $\mathrm{PGF}_{2 u}$ infusion (Table 2). In Expt 3, mRNA encoding IGF-I increased $(P<0.05)$ between days 3 and 6 of the oestrous cycle and then did not change during the remainder of the cycle (Table 3). Concentrations of mRNA encoding GH-R were not different throughout the oestrous cycle (Table 3).

\section{Discussion}

In all three experiments, concentrations of progesterone in sera and luteal masses were similar to values observed in previous studies in sheep indicating that corpora lutea were collected from donor ewes that responded as expected (Diekman et al., 1978; Niswender et al., 1986; Farin et al., 1990; Hawkins et al., 1993). 
Table 3. Serum concentrations (LSM \pm SEM) of progesterone, luteal mass and luteal concentrations of mRNA encoding IGF-I and GH-receptor on selected days of the ovine oestrous cycle

\begin{tabular}{|c|c|c|c|c|}
\hline \multirow[b]{2}{*}{$\begin{array}{l}\text { Day of } \\
\text { cycle }\end{array}$} & \multirow{2}{*}{$\begin{array}{l}\text { Concentration of } \\
\text { progesterone } \\
\text { in serum } \\
\left(\mathrm{ng} \mathrm{ml}-{ }^{-1}\right)^{*}\end{array}$} & \multirow[b]{2}{*}{$\begin{array}{l}\text { Luteal mass } \\
\qquad(\mathrm{mg})^{*}\end{array}$} & \multicolumn{2}{|c|}{ Luteal concentration } \\
\hline & & & $\begin{array}{l}\text { IGF-I mRNA } \\
\text { (fmoles } \mu \mathrm{g}\end{array}$ & $\begin{array}{l}\text { GH-R mRNA } \\
A^{+} \text {RNA) }\end{array}$ \\
\hline 3 & $0.37 \pm 0.35^{\mathrm{a}}$ & $103 \pm 44^{\mathrm{a}}$ & $0.19 \pm 0.03^{\mathrm{a}}$ & $0.55 \pm 0.06$ \\
\hline 6 & $1.42 \pm 0.35^{b}$ & $278 \pm 44^{b}$ & $0.30 \pm 0.03^{b}$ & $0.48 \pm 0.06$ \\
\hline 9 & $2.50 \pm 0.35^{c}$ & $398 \pm 44^{b}$ & $0.29 \pm 0.03^{b}$ & $0.51 \pm 0.06$ \\
\hline 12 & $3.21 \pm 0.35^{c}$ & $593 \pm 44^{\mathrm{c}}$ & $0.30 \pm 0.03^{\mathrm{b}}$ & $0.48 \pm 0.06$ \\
\hline 15 & $3.16 \pm 0.35^{c}$ & $610 \pm 44^{c}$ & $0.33 \pm 0.03^{b}$ & $0.49 \pm 0.06$ \\
\hline
\end{tabular}

IGF-I: insulin-like growth factor I; GH-R: growth hormone receptor.

*Data have been published by Juengel et al. (1996).

a.b,c Within each parameter, means with different letters were significantly different $(P<0.05)$.

Steady-state concentrations of mRNA encoding IGF-I increased during luteal development in Expts 1 and 3, in a similar way to the increase observed for IGF-I protein and mRNA in developing bovine corpora lutea (Einspanier et al., 1990). However, Perks et al. (1995), using in situ hybridization techniques, did not detect an increase in concentrations of mRNA encoding IGF-I in ovine corpora lutea throughout the oestrous cycle. Differences between the findings in the two studies are most likely related to the methods by which mRNA was measured but could also be due to differences between breeds of ewe. As seen in other tissues (Hynes et al., 1987; Roberts et al., 1987; Hernandez et al., 1989), administration of GH increased mRNA encoding IGF-I in luteal tissue. Ovaries collected from hypophysectomized, sexually immature rats that had been treated with $\mathrm{GH}$ showed no increase in mRNA encoding IGF-I (Hernandez et al., 1989). A similar lack of effect of GH on IGF-I expression has been observed in ovine granulosa cells, even though $\mathrm{GH}$ increased progesterone synthesis in these cells, indicating that an active GH receptor was present (Wathes et al, 1995). Thus, regulation of mRNA encoding IGF-I in luteal cells may differ from that observed in granulosa cells.

While concentrations of mRNA encoding GH-R did not change during the oestrous cycle, removal of pituitary hormones decreased the amount of this mRNA. A similar decline in mRNA encoding GH-R in rat ovaries occurs after hypophysectomy (Carlsson et al., 1993). Replacement of LH, but not $\mathrm{GH}$, resulted in the return of expression of mRNA encoding $\mathrm{GH}-\mathrm{R}$ to normal values. This finding is in contrast to that of Carlsson et al. (1993), who observed an increase in ovarian expression of mRNA encoding GH-R following GH treatment of hypophysectomized rats. However, they demonstrated that follicles as well as corpora lutea express mRNA encoding GH-R, thus which cell type was affected by GH treatment could not be determined in their study. Thus, one of the luteotrophic roles of LH may be to maintain concentrations of mRNA encoding GH-R and ultimately responsiveness of luteal tissue to GH.

The administration of $\mathrm{PGF}_{2 \alpha^{\prime}}$ which induced luteolysis, did not affect luteal concentrations of mRNA encoding either IGF-I or GH-R. Expression of mRNA encoding IGF-I and of IGF-I was shown to be quite high in the corpus albicans when compared with the corpus luteum (Leeuwenberg et al., 1995; Perks et al., 1995). However, the earliest time point examined by these investigators was $48 \mathrm{~h}$ after induction of luteal regression, long after secretion of progesterone had diminished to basal values and luteal cell death had begun. Thus, it does not seem likely that a change in IGF-I synthesis or a decreased responsiveness of the corpus luteum to $\mathrm{GH}$ initiates the decline in progesterone synthesis or luteal cell death observed during luteal regression. However, this does not preclude a role of decreased IGF-I action on the corpus luteum during the time of luteal regression. For instance, binding of IGF-I by IGF-binding proteins could render IGF-I inactive; or a decrease in luteal receptors for IGF-I could limit its effect. Perks et al. (1995) observed an increase in IGF-I binding during luteal regression that was not associated with greater amounts of mRNA encoding the IGF-I receptor and proposed that this increased binding was due to greater amounts of IGF-II receptor or IGF-binding proteins. Messenger RNAs encoding several of the IGF-binding proteins have been detected in corpora lutea (Nakatani et al., 1991; Erickson et al., 1992; Samaras et al., 1992) indicating a role for these proteins in regulation of IGF activity in luteal tissue.

In conclusion, responsiveness of the corpus luteum to $\mathrm{GH}$ and the luteal synthesis of IGF-I are likely regulators of luteal development and function. Luteinizing hormone may maintain luteal responsiveness to $\mathrm{GH}$ by increasing mRNA encoding GH-R and presumably GH-R and GH support luteal expression of mRNA encoding IGF-I. Locally produced IGF-I may play a role in early luteal growth and development as concentrations of mRNA encoding IGF-I increased during this time. However, $\mathrm{PGF}_{2 \alpha}$ had no effect on concentrations of mRNA encoding IGF-I or GH-R during the early stage of luteolysis indicating that decreased concentrations of mRNA encoding GH-R or IGF-I are not a prerequisite for either the antisteroidogenic or luteal cell death effects of $\mathrm{PGF}_{2 a}$.

This research was supported by $\mathrm{NIH}$ grant HDI1590 and the Colorado Agricultural Experiment Station. The authors wish to thank Monsanto for their generous donation of Sometribove. They appreciate the invaluable technical assistance of M. Gallegos, B. Meberg, C. Moeller and K. Sutherland. They would also like to thank H. R. Sawyer, M. D. Fanning, A. M.Turzillo, C. M. Discafani, M. K. Guy and Downloaded from Bioscientifica.com at 04/26/2023 09:49:15AM 
T. R. Tandeski for their help with surgeries and collection of tissue. The authors express their appreciation to the National Hormone and Pituitary Program for the gift of NIAMDD-oLH-S24.

\section{References}

Adams TE, Baker L, Fiddes RJ and Brandon MR (1990) The sheep growth hormone receptor: molecular cloning and ontogeny of mRNA expression in the liver Molecular and Cellular Endocrinology 73 135-145

Adashi EY, Resnick CE, D'Ercole AJ, Svoboda ME and Van Wyk JJ (1985a) Insulin-like growth factors as intraovarian regulators of granulosa cell growth and function Endocrine Reviews 6 400-419

Adashi EY, Resnick CE, Svoboda ME and Van Wyk JJ (1985b) Somatomedin-C enhances induction of luteinizing hormone receptors by follicle stimulating hormone in cultured rat granulosa cells Endocrinology 116 2369-2375

Adashi EY, Resnick CE, Svoboda ME and Van Wyk JJ (1986) Synergistic interactions of somatomedin- $C$ with adenosine $3^{\prime}, 5^{\prime}$-cyclic monophosphatedependent granulosa cell agonist Biology of Reproduction 34 81-88

Adashi EY, Resnick CE, Hernandez ER, May JV, Knecht M, Svoboda JE and Van Wyk JJ (1988) Insulin-like growth factor-I as an amplifier of folliclestimulating hormone action: studies on mechanism(s) and site(s) of action in cultured rat granulosa cells Endocrinology 122 1583-1591

Badley E, Bishop GA, St John T and Frelinger JA (1988) A simple, rapid method for the purification of poly $(A)^{+}$RNA Biotechniques $6114-116$

Carlsson B, Nilsson At Isaksson OGP and Billig H (1993) Growth hormonereceptor messenger RNA in the rat ovary: regulation and localization Molecular and Cellular Endocrinology 95 59-66

Chen EY and Seeburg PH (1985) Laboratory methods. Supercoil sequencing: a fast and simple method for sequencing plasmid DNA DNA 4 165-170

Chomcynski P and Sacchi N (1987) Single-step method of RNA isolation by acid guanidinium thiocyanate-phenol-chloroform extraction Analytical Biochemistry 162 156-159

Clarke I], Cummins JT and de Kretser DM (1983) Pituitary gland function after disconnection from direct hypothalamic influences in the sheep Neuroendocrinology 36 376-384

Constantino CX, Keyes PL and Kostyo JL (1991) Insulin-like growth factor-I stimulates steroidogenesis in rabbit luteal cells Endocrinology 128 1702-1708

Davoren JB and Hseuh AJW (1986) Growth hormone increases ovarian levels of immunoreactive somatomedin C/insulin-like growth factor I in vivo. Endocrinology 118 888-890

Devoto L, Kohen P, Castro O, Vega M, Troncoso and Charreau E (1995) Multihormonal regulation of progesterone synthesis in cultured human midluteal cells Journal of Clinical Endocrinology and Metabolism $801566-1570$

Diekman MA, O'Callaghan P. Nett TM and Niswender GD (1978) Validation of methods and quantification of luteal receptors for $\mathrm{LH}$ throughout the estrous cycle and early pregnancy in ewes Biology of Reproduction 19 999-1009

Einspanier R, Miyamoto A, Schams D, Muller M and Brem G (1990) Tissue concentration, mRNA expression and stimulation of IGF-I in luteal tissue during the oestrous cycle and pregnancy of cows Journal of Reproduction and Fertility $90439-445$

Erickson GF, Nadatani A, Ling N and Shimasaki S (1992) Localization of insulin-like growth factor-binding protein-5 messenger ribonucleic acid in rat ovaries during the estrous cycle Endocrinology 130 1867-1878

Farin CE, Nett TM and Niswender GD (1990) Effects of luteinizing hormone on luteal cell populations in hypophysectomized ewes Journal of Reproduction and Fertility 88 61-70

Feinberg AP and Volgelstein B (1983) A technique for radiolabelling DNA restriction endonuclease fragments to high specific activity Analytical Biochemistry 132 6-13

Fotsis T, Murphy C and Gannon I (1990) Nucleotide sequence of the bovine insulin-like growth factor 1 (IGF-I) and its IGF-IA precursor Nucleic Acids Research 18676

Guy MK, Juengel JL, Tandeski TR and Niswender GD (1995) Steady-state concentrations of mRNA encoding the receptor for luteinizing hormone during the estrous cycle and following prostaglandin $\mathrm{F}_{2 u}$ treatment of ewes Endocrine 3 585-589

Hawkins DE, Belfiore CJ, Kile JP and Niswender GD (1993) Regulation of messenger ribonucleic acid encoding $3 \beta$-hydroxysteroid dehydrogenase $/ \Delta^{5}$ $\Delta^{4}$-isomerase in the ovine corpus luteum Biology of Reproduction 48 $1185-1190$
Hernandez ER, Roberts CT, Jr, LeRoith D and Adashi EY (1989) Rat ovarian insulin-like growth factor I (IGF-I) gene expression is granulosa cell-selective: 5 '-untranslated mRNA variant representation and hormonal regulation Endocrinology 125 572-574

Hynes MA, Van Wyk JJ, Brooks PJ, D'Ercole AJ, Jansen J and Lund PK (1987) Growth hormone dependence of somatomedin-C/insulin-like growth factor I and insulin-like growth factor II messenger ribonucleic acids Molecular Endocrinology 1 233-243

Juengel JL, Guy MK, Tandeski TR, McGuire WJ and Niswender GD (1994) Steady-state concentrations of messenger ribonucleic acid encoding cytochrome P450 side-chain cleavage and $3 \beta$-hydroxysteroid dehydrogenase/ $\Delta^{5}, \Delta^{4}$ isomerase in ovine corpora lutea during the estrous cycle Biology of Reproduction 51 380-384

Juengel JL, Nett TM Tandeski TR, Eckery DC, Sawyer HR and Niswender GD (1995) Effect of luteinizing hormone and growth hormone on luteal development in hypophysectomized ewes Endocrine 3 323-326

Juengel JL, Wiltbank MC, Meberg BM and Niswender GD (1996) Regulation of steady state concentrations of messenger ribonucleic acid encoding prostaglandin $\mathrm{F}_{2} \alpha$ receptor in ovine corpus luteum Biology of Reproduction $\mathbf{5 4}$ 1096-1102

Leeuwenberg BR, Hurst PR and McNatty KP (1995) Expression of IGF-I mRNA in the ovine ovary Journal of Molecular Endocrinology 15 251-258

Lucy MC, Collier RJ, Kitchell ML, Dibner JJ, Hauser SP and Kriui GG (1993) Immunohistochemical and nucleic acid analysis of somatotropin receptor populations in the bovine ovary Biology of Reproduction 48 1219-1227

McArdle CA and Holtorf A-P (1989) Oxytocin and progesterone release from bovine corpus luteal cells in culture: effects of insulin-like growth factor I, insulin, and prostaglandins Endocrinology 124 1278-1286

McGuire WJ, Juengel JL and Niswender GD (1994) Protein kinase C second messenger system mediates the antisteroidogenic effects of prostaglandin $\mathrm{F}_{2} \alpha$ in the ovine corpus luteum in vivo. Biology of Reproduction 51 800-806

Nakatani A, Shimasaki S, Erickson GF and Ling N (1991) Tissue-specific expression of four insulin-like growth factor-binding proteins (1, 2, 3, and 4) in the rat ovary Endocrinology 129 1521-1529

Niswender GD (1973) Influence of site of conjugation on the specificity of antibodies to progesterone Steroids 22 413-424

Niswender GD and Nett TM (1994) Corpus luteum and its control in infraprimate species. In The Physiology of Reproduction Vol. I pp 781-816 Eds E Knobil and JD Neill. Raven Press, New York

Niswender GD, Farin CE, Gamboni R, Sawyer HR and Nett TM (1986) Role of luteinizing hormone in regulating luteal function in ruminants Journal of Animal Science 63 (Supplement 2) 1-13

Obasiolu CCW, Khan-Dawood FS and Dawood MY (1992) Insulin-like growth factor I receptors in human corpora lutea Fertility and Sterility 57 1235-1240

Parmer TG, Roberts CT, Jr, LeRoith D, Adashi EY, Khan I, Solan N, Nelson S, Zelberstein M and Gibori G (1991) Expression, action, and steroidal regulation of insulin-like growth factor-I (IGF-I) and IGF-I receptor in the rat corpus luteum: their differential role in the two cell populations forming the corpus luteum Endocrinology 129 2924-2932

Perks CM, Denning-Kendall PA, Gilmour RS and Wathes DC (1995) Localization of messenger ribonucleic acids for insulin-like growth factor I (IGF-I), IGF-II and the type I IGF receptor in the ovine ovary throughout the estrous cycle Endocrinology 136 5266-5273

Pratt SL and Anthony RV (1995) The growth hormone receptor messenger ribonucleic acid present in ovine fetal liver is a variant form Endocrinology $136 \quad 2150-2155$

Roberts CT, Jr, Lasky SR, Lowe WL, Jr, Seaman WT and LeRoith D (1987) Molecular cloning of rat insulin-like growth factor I complementary deoxyribonucleic acids: differential messenger ribonucleic acid processing and regulation by growth hormone in extrahepatic tissues Molecular Endocrinology $1243-248$

Samaras SE, Hagen DR, Shimasaki S, Ling N and Hammond JM (1992) Expression of insulin-like growth factor-binding protein-2 and -3 messenger ribonucleic acid in the porcine ovary: localization and physiological changes Endocrinology 130 2739-2744

Sambrook J, Fritsch EF and Maniatis T (1989) Molecular Cloning: A Laboratory Manual (2nd Edn). Coldspring Harbor Laboratory Press, New York

SAS (1987) SAS User's Guide, Statistics. Statistical Analysis System Institute, Cary NC

Sauerwein H, Miyamoto A, Gunther J, Meyer HHD and Schams D (1992) Binding and action of insulin-like growth factors and insulin in bovine luteal tissue during the oestrous cycle Journal of Reproduction and Fertility 96 103-115 
Smith MF, Mclntush EW and Smith GW (1994) Mechanisms associated with corpus luteum development Journal of Animal Science 72 1857-1872

Talavera $\mathrm{F}$ and Menon KMJ (1991) Studies on rat luteal cell response to insulin-like growth factor I (IGF-I): identification of a specific cell membrane receptor for IGF-I in the luteinized rat ovary Endocrinology 129 1340-1346
Vandehaar MJ, Sharma BK and Fogwell RL (1995) Effect of dietary energy restriction on the expression of insulin-like growth factor- $I$ in liver and corpus luteum of heifers Journal of Dairy Science 78 832-841

Wathes DC, Perks CM, Davis AJ and Denning-Kendall PA (1995) Regulation of insulin-like growth factor-I and progesterone synthesis by insulin and growth hormone in the ovine ovary Biology of Reproduction 53 882-889 